\section{Prescribed burning in Italy: issues, advances and challenges}

\author{
Davide Ascoli, Giovanni Bovio
}

Prescribed burning has been carried out since the late 1970s in several southern European countries. Italy hosted some pioneer experiences in the early ' $80 \mathrm{~s}$, but these did not follow up into practical implementation, and few studies and applications were carried out in subsequent years. In the last decade, a new interest arose and several experiences were carried out. We aim to illustrate the limitations, advances and challenges of prescribed burning in Italy by reviewing the national literature of the last 40 years on this subject. Unfavorable land characteristics, conflicting management goals, a hostile socio-cultural environment, and an inadequate regulatory framework have supposedly limited the application of prescribed burning in Italy. Nevertheless, in the last 20 years the legislation at the regional level has been updated to consider the use of fire, and new procedures to authorize prescribed fires allowed for experiments and application, even within National Parks. From 2005 to 2012, prescribed burning programs for fire hazard reduction, forest and range management, biodiversity conservation and firefighter training were implemented throughout Italy. Several vegetation and fuel types were involved (e.g., broadleaved and coniferous forests, Mediterranean and continental shrubland, grassland, slash). Studies on fire behavior and effects helped to set prescriptions for specific objectives and environments. Results were transferred to professionals through training sessions. Some of the challenges ahead are improving the legislative framework, e.g., by introducing a certification for the use of fire, and addressing issues of pastoral fire through conflict resolution programs. Prescribed burning in Italy could be developed by committing to carry out ecological studies on its implications to silviculture, range management and habitat conservation.

Keywords: Wildfire, Integrated Fire Management, Biodiversity, Historical Fire Use

\section{Introduction}

Prescribed burning (PB) has been used worldwide since the first half of the $20^{\text {th }}$ century for fire hazard reduction, forest and range management and biodiversity conservation (Pyne 1997). In Europe, the planned use of fire has a long history of application, e.g., in heathland management in the Atlantic area (Davies et al. 2008), understory burning in southern Europe (Lázaro 2010), forest regeneration in Scandinavia (Granström

$\square$ Dept. AgriForFood, University of Turin, v. Leonardo da Vinci 44, I-10095 Grugliasco (TO - Italy)

\section{(a) Davide Ascoli (d.ascoli@unito.it)}

Received: Sep 29, 2012 - Accepted: Nov 20, 2012

Citation: Ascoli D, Bovio G, 2013. Prescribed burning in Italy: issues, advances and challenges. iForest 6: 79-89 [online 2013-0207] URL: http://www.sisef.it/iforest/ contents?id=ifor0803-005

Communicated by: Marco Borghetti chief of the Fire Service of the National Forest Service, acknowledged the potential use of $\mathrm{PB}$ to rationalize the use of fire in range management, prevent pastoral fires from originating wildfire, and improve rangeland productivity. $\mathrm{He}$ acknowledged the applicability of PB for fire hazard reduction and tree regeneration in Mediterranean pine forests and for fuel break management, and its potential value in firefighter training. Experimental PB in Mediterranean pine forests (Tuscany) and for fuel break management (Sardinia) followed in the 80 s under the supervision of Istituto Sperimentale di Selvicoltura (Buresti \& Sulli 1983, Calabri 1988). Despite "promising" results (Calabri 1988), the outcomes were not monitored in the following years, nor implemented in ordinary forest management. Unlike France, Portugal and Spain, where experiments were followed by investments in research, application and training (Silva et al. 2010), interest in PB in Italy died off. Only one experiment is documented in the $90 \mathrm{~s}$, aimed at fuel break management in Sardinia (Massaiu 1999). In the last 10 years, however, PB regained attention. Seminars, training courses and scientific experiments were carried out in cooperation with firefighting organizations, local administrators, universities and professionals from several regions (Ascoli et al. 2012).

This work aims to: (i) ascertain the reasons for a limited or delayed development of PB in Italy, in comparison with other European (particularly Mediterranean) countries; (ii) summarize goals, methods and results of PB activities carried out in Italy during the last 10 years; (iii) point out open research questions to be addressed for the future development of PB in the country.

2001). However, PB as a professional land management technique (i.e., having clear prescriptions and evaluation protocols) developed at the end of 1970s (Silva et al. 2010). In central and northern Europe, PB is used mainly for conservation and forest regeneration purposes. It is applied extensively in the United Kingdom (Davies et al. 2008), Sweden (over 4000 ha $\mathrm{yr}^{-1}$ - Granström 2001), Finland (2000 ha $\mathrm{yr}^{-1}$ - VanhaMajamaa et al. 2007), Germany (750 ha yr ${ }^{-1}$ Held A., personal communication), while in other countries it has experimental application (Lázaro 2010). In the Mediterranean area, PB programs were designed in the 80 s90s for fire hazard reduction in France, Portugal and Spain, leading to an increase in trained personnel (Silva et al. 2010). Burnt area is currently around 5000 ha per year in France, 2000 ha in Portugal and 1000 ha in Spain, and the use of PB has been extended to habitat conservation, grazing, game and forest management (Lázaro 2010).

In Italy, interest in PB rose in the late 70 s (Susmel 1977), about at the same time than in other European countries. Calabri (1981),

\section{Issues of prescribed burning in Italy}

Several authors evidenced potential limitations to the application of PB in Italy (Susmel 1973, Calabri 1981, Buresti \& Sulli 1983, Calabri 1988, Stefani 1985, Leone et al. 1999). These can be due to unfavorable land characteristics, conflicting management goals, hostile socio-cultural environment, or inadequate legislation (Tab. 1).

\section{Land characteristics}

Forest species traits, and an overdeveloped rural-urban interface (RUI), are the main ecological and geographic issues that could have been limiting the use of PB in Italy (Susmel 1973, Calabri 1981, Leone et al. 1999). Fire-adapted forest types where PB is commonly applied in southern Europe (conifers: Pinus canariensis Smith, $P$. halepensis Mill., P. laricio Poiret., $P$. pinaster Ait., $P$. pinea L.; broadleaves: Eucalyptus sp., Quercus $s p$.) are sporadic in Italy, i.e., $7 \%$ of total 
Tab. 1 - Limitations to the use of prescribed burning in Italy according to several Italian authors.

\begin{tabular}{ll}
\hline Limitations & Description \\
\hline $\begin{array}{l}\text { Land } \\
\text { characteristics }\end{array}$ & $\begin{array}{l}\text { Extent of rural-urban interface; forests, shrublands and rangelands in } \\
\text { mountain territories; vegetation constituted by fire sensitive species; extent } \\
\text { and fragmentation of the private property. }\end{array}$ \\
$\begin{array}{l}\text { Management } \\
\text { policies }\end{array}$ & $\begin{array}{l}\text { Priority investments in fire control policies; preference towards forest ex- } \\
\text { pansion and rangeland reduction; preference for ecological successions to- } \\
\text { wards late-successional and less flammable forests; silviculture mainly fo- } \\
\text { cused on natural tree regeneration. }\end{array}$ \\
Cultural & $\begin{array}{l}\text { Fear of fire; lost of expertise in traditional fire uses by the rural population; } \\
\text { surreptitious use of fire in agricultural and pastoral systems; public opinion } \\
\text { mainly accustomed to fire control policies; poor knowledge of ecological } \\
\text { effects related to fire. }\end{array}$ \\
& $\begin{array}{l}\text { Absence of a national legislative framework; high heterogeneity of the le- } \\
\text { gislation at the regional level; confusion between prescribed burning and } \\
\text { other fire uses; lack of clear authorization processes and definition of liab- }\end{array}$ \\
& ility; lack of certification programs.
\end{tabular}

forest cover by conifers, $19.1 \%$ of which has an uneven-aged structure, and $13 \%$ by broadleaves (Tab. 2 - INFC 2005). On the other hand, shrub communities usually targeted by PB (i.e., heathlands, Mediterranean scrublands) represent $70 \%$ of shrub-type formations in the country (INFC 2005). However, Susmel (1973), a leading Italian ecologist of the $20^{\text {th }}$ century, maintained that $\mathrm{PB}$ could accelerate the degradation of Mediterranean scrublands that had been repeatedly burnt by wildfire between the $50 \mathrm{~s}$ and the 70 s. In a national survey on the awareness and perception of fire by professional foresters (Leone et al. 1999), $72 \%$ of the interviewees answered that potential damage to vegetation was the main limit to $\mathrm{PB}$ implementation in the field.

Calabri (1988) highlighted that PB can be problematic in complex topographies and highly variable wind patterns. Some $66 \%$ of Italian forests is located at elevations $>500$ $\mathrm{m}$, and one third on slopes $>60 \%$ (Tab. 2 INFC 2005). However, this issue is not controversial in other countries such as Portugal (where PB is carried out on slopes of $0-68 \%$ and elevations of 150 to $1000 \mathrm{~m}$ a.s.1. Fernandes \& Botelho 2004) or France, where PB is applied in sites that are morphologically similar (Lambert 2010) or equivalent (Bernard-Laurent \& Weber 2007) to the Italian mountains.

Another issue, shared by all southern European countries, is the preponderance of private ownership and real estate fragmentation in forests (Calabri 1981 - Tab. 2). However, this is relevant also in other Mediterranean countries where it has been addressed by involving landowners in PB-related decisions according to a participatory approach to land planning, as illustrated below (e.g., BernardLaurent \& Weber 2007, Lambert 2010 , Vélez 2010).

Finally, it has been suggested that PB in presence of an overdeveloped RUI could be detrimental to health and safety in urban areas (e.g., air quality, road visibility - Calabri 1988). Population has been rising steadily in Italy since the late $80 \mathrm{~s}$, and population and road density are currently among the highest in southern Europe (Tab. 2). Following depopulation in mountain areas (62 inhabitants $\mathrm{km}^{-2}$, on average), human pressure has increased in the lowlands and coastal regions (Falcucci et al. 2007, Corona et al. 2012). This issue is complex, and shared by other southern European countries (Lázaro 2010). For example, in the Alpes-Maritimes (southern France) population density is comparable to Italy (250 inhabitants $\mathrm{km}^{-2}$ ),

Tab. 2 - Land and wildfire characteristics of Italy and of south European countries where prescribed burning is used. (1): Forest data have been derived from National Forest Inventories published on respective web sites (Italy: Inventario Nazionale delle Foreste e dei Serbatoi Forestali di Carbonio - http://www.sian.it/inventarioforestale/; France: Inventaire Forestal Nacional - http://www.ifn.fr/spip/; Portugal: Inventário Florestal Nacional - http://www.icnf.pt/florestas/ifn/; Spain: Inventario Forestal Nacional - http://www.magrama.gob.es/es/biodiversidad/temas/inventarios-nacionales/inventario-forestal-nacional/); (2): Statistics for the French territory have been calculated only for southern Departments where prescribed burning is implemented on a broad scale: Provence-Alpes-Cote-d'Azur, Corse, Languedoc-Rousillon, Midi-Pyrénnées, Aquitaine; (3) From respective National Forest Fires Inventories and Schmuck et al. 2011; (4) Data from Catry et al. 2010.

\begin{tabular}{|c|c|c|c|c|}
\hline Land characteristics ${ }^{(1)}$ & Italy & France $^{(2)}$ & Portugal & Spain \\
\hline Land area $\left(\mathrm{km}^{2}\right)$ & 301336 & 154113 & 92391 & 505957 \\
\hline Population density (pers. $/ \mathrm{km}^{2}$ ) & 202 & 90 & 115 & 89 \\
\hline Road density $\left(\mathrm{km} / \mathrm{km}^{2}\right)$ & 1.50 & 1.77 & 0.87 & 1.32 \\
\hline Forest area (ha) & 8705220 & 8182000 & 3458556 & 18571403 \\
\hline Private Property $(\%)$ & $66 \%$ & $80 \%$ & $93 \%$ & $70 \%$ \\
\hline Shrub/grassland area (ha) & 4432910 & 1907000 & 1926630 & 25141335 \\
\hline Private Property $(\%)$ & (shrub) $15 \%$ & $89 \%$ & $88 \%$ & n.a. \\
\hline$\%$ forests at elevation $0-500 \mathrm{~m}$ & 34 & 53 & 87 & n.a. \\
\hline$\%$ forests at $500-1000 \mathrm{~m}$ & 38 & 28 & 12 & n.a. \\
\hline$\%$ forests $>1000 \mathrm{~m}$ & 28 & 18 & 1 & n.a. \\
\hline$\%$ forests with slope $>60 \%$ & 29 & 22 & n.a. & n.a. \\
\hline Conifer sp. where prescribed fire is used in South Europe & 7 & 18 & 29 & 53 \\
\hline ( $\%$ tot. private forest) & $50 \%$ & $90 \%$ & $86 \%$ & n.a. \\
\hline Broadleaf sp. where prescribed fire is used in South Europe & 23 & 24 & 26 & 15 \\
\hline \multicolumn{5}{|l|}{ Wildfire characeristics ${ }^{(3)}$} \\
\hline Average burnt area (ha $\left.\mathrm{yr}^{-1} ; 1980-2010\right)$ & 118085 & 20332 & 113033 & 178941 \\
\hline Burnt forest ( $\%$ total burnt area) & $41 \%$ & n.a. & $53 \%$ & $38 \%$ \\
\hline$\%$ tot. vegetation area burnt yearly $(\%)$ & 1.29 & 0.20 & 2.10 & 0.41 \\
\hline Intentional fires $(\%$ total $){ }^{(4)}$ & 80 & 21 & 38 & 68 \\
\hline
\end{tabular}


and particularly high along the coasts (888 inhabitants $\mathrm{km}^{-2}$ ). Here, PB covers $\sim 1600$ ha $\mathrm{yr}^{-1}$ and is mainly used for fire hazard reduction, also at the rural-urban interface. Strong efforts have been sustained in order to mitigate smoke-related issues, mainly by developing suitable fire prescriptions and implementing conflict resolution strategies (Bernard-Laurent \& Weber 2007).

\section{Land management goals}

The adequacy of PB depends on the management goals being prioritized (Susmel 1973, Calabri 1981, Stefani 1985). Universal acknowledgment is given to the wildfire issue, which is the main cause of damage to Italian forests (INFC 2005), and has been occurring in several catastrophic fire seasons in the last 30 years (Schmuck et al. 2011). The ratio of the yearly burnt area to total vegetation cover in Italy is second only to Portugal (Tab. 2). Nevertheless, investing in PB as a preventive measure was considered to be conflicting with other land management policies (Susmel 1973, Stefani 1985, Calabri 1988).

In the wake of a widespread debate on the profitability of range $v s$. forestry systems (Stefani 1985), Susmel (1973) suggested that periodic wildfires in Mediterranean areas in the $60 \mathrm{~s}-70 \mathrm{~s}$, caused mostly by shepherds and criminal action by real estate constructors, were the main reason for hydrogeological hazard, loss of plant diversity and lack of adult stages in shrubland communities. Consequently, he recommended reducing fire frequency by a fire suppression strategy to promote late-successional, "climacic" forest (e.g., Quercus spp.) that could produce higher timber and landscape values, and have a lower flammability.

In Italy, the history of fire management has been dominated by fire control polices, often at the expense of investments in silvicultural prevention (Bovio 2006). In several countries outside Europe, the transition from fire control to fire management policies, which include PB, occurred as a result of catastrophic fires that caused much distress in firefighting systems (McArthur 1969, Kilgore 1976, Pyne 1997). Likewise, PB in southern Europe received a boost after large fires in summer 2003 and 2005, when a novel fire management approach, integrating wildfires within prescription, the planned application of fire, and traditional fire uses (e.g., pastoral burning) to meet the overall objectives of land management, was developed (Silva et al. 2010). In Italy, however, critical seasons such as the summer of 2007 (227 729 ha burnt, the worst season of the last 30 years Schmuck et al. 2011) have not lead to significant investments in land planning and fuel management (Delogu 2012). Rather, fire suppression policies have been progressively enforced by significant amounts of public financial resources (Fiorucci et al. 2011). In other words, wildfires have been dealt with more as a civil protection emergency than as a land management issue (Bovio 2006). Opinion was that the costs of extinction could be backed up by public interests such as employment opportunities, political convenience, industry business or commerce. Measures of preventive silviculture such as $\mathrm{PB}$ were more difficult to implement, and could not find a comparable economic justification (Calabri 1988).

Another concern has been that forest management in Italy is aimed primarily at promoting natural regeneration and uneven-aged stand structures, that were considered incompatible with the use of fire in the forest (Susmel 1973, Calabri 1981, Stefani 1985). Forest management systems adopted in other countries, especially in even-aged conifer stands where PB is applied, are based on artificial regeneration. Afforestation has been carried out in many southern European countries in the $20^{\text {th }}$ century (Moreira et al. 2011 ), including Italy, where $40 \%$ of evenaged conifer forests are planted (INFC 2005). However, plantations have not been managed for production purposes (Vallauri et al. 2002), nor followed arboricultural planning methods such as those applied, e.g., in Portugal (Fernandes \& Botelho 2004). Since the main goal of Italian plantations was to facilitate the establishment of native hardwoods, PB was feared to alter the desired succession dynamics (Calabri 1981). In regard to industrial plantations, in Italy these are only $1.4 \%$ of total forest cover (INFC 2005 ), and only $25 \%$ of these includes tree species commonly subject to PB in European countries. In addition, unlike those in other countries (e.g., Fernandes et al. $2012 a$ ), only $18.4 \%$ of Italian private industrial plantations belongs to large companies, firms and industries (INFC 2005); the interest of small landowners in financing measures of preventive silviculture is much more limited.

\section{Socio-cultural issues}

The fear of fire is one of the greatest limits to PB in Italy (Calabri 1988). Professionals are afraid to lose control of the flame front (Leone et al. 1999). Susmel (1973) argues that centuries of detrimental fire use, especially by shepherds, have contributed to exacerbate the public perception of fire and fire use. In particular, after a long history of fire use, the socio-economic changes that occurred in rural areas at the end of the $16^{\text {th }}$ century changed the way fire was being used in agriculture and livestock breeding, and have been affecting negatively its social acceptance (Calabri 1981, Delogu \& Cabiddu 2009, Conedera \& Krebs 2010).

Fire has long been used for agro-silvo-pastoral purposes in Italy (Sereni 1981). In the
Greco-Roman world, the use of fire was widespread in Mediterranean Italy (Susmel 1973) to create or regenerate pastures, fertilize fields, hunt, and control pests (Sereni 1981, Pyne 1982). Also in the Alps, between $6500 \mathrm{BC}$ and $800 \mathrm{AD}$, slash and burn (debbio) was broadly used to open new pastures and agricultural fields (Ali et al. 2005, Tinner et al. 2005, Carcaillet et al. 2009, Favilli et al. 2010). However, starting from the late Middle Ages, the use of fire in northern Italy decreased (Conedera \& Krebs 2010). Pyne (1997), describing fire uses in central Europe, reports that in the $16^{\text {th }}$ century the conversion of most forest areas into agricultural land and pastures made the use of fire less necessary. Population growth and the development of cities built with flammable materials demanded greater control of fires in RUI areas. In the $19^{\text {th }}$ century, the shortage of timber resources, forests privatization, and the development of timber industry (Puettmann et al. 2009) required increased fire control and the prohibition of agro-pastoral use of fire (Pyne 1982). Similar dynamics occurred north and south of the Alps, so that in the last three centuries the use of fire has been increasingly limited and confined to the mere management of marginal agricultural and pastoral areas (Ascoli \& Bovio 2010a, Conedera \& Krebs 2010).

In the lowlands, fire has been used until recently to regenerate reed stands of Phragmites australis (Cav.) Trin., whose sprouts were used for roofing (Razzoli 2010). Fire is still used to remove the stubble in rice fields but must comply with special regulations (Bovio \& Ascoli 2012). In forests, fire has been used until the II World War to remove the understory in chestnut orchards (Calabri 1988). In rangelands, fire has been a common practice to control shrub and tree encroachment until the beginning of the $20^{\text {th }}$ century (Conedera \& Krebs 2010), e.g., by eliminating Swiss stone pine in low-density, grazed larch forests (Ali et al. 2005, Schulze et al. 2007). Fire scars on old larch trees (Fig. 1) preserve the memory of this practice (Genries et al. 2009). The use of fire in these areas has declined in the last century, due to the decrease of livestock units and the improvement in farming methods. However, shepherds throughout the Alps still practice it occasionally (Conedera \& Krebs 2010). This habit is controversial: on one hand, burning helps maintaining the pastures, on the other it is now applied surreptitiously in high fire danger seasons resulting in unclear effects on the ecosystem and ultimately higher costs for fire control systems (Ascoli \& Bovio 2010a). These issues are common in central and southern Italy (Delogu \& Cabiddu 2009), where the fire is widely used to remove stubble and regenerate pastures (Fig. 2). Irresponsible or illegal use of fire is a major cause of wildfire in southern Italy (Ca- 
Fig. 1 - Multiple fire scars on a larch trunk. In grazed larch forests of the Alpine region it is common to observed old larch individuals with over-

lapped fire scars at the trunk base indicating recurrent fires due to pastoral burn practices to maintain open forests.

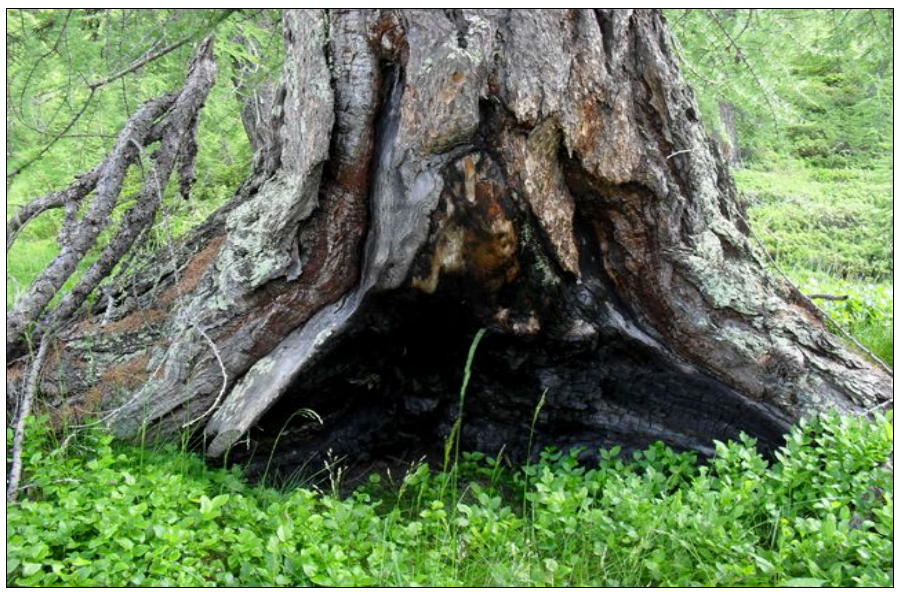

labri 1988, Mazzoleni et al. 2001, Lovreglio et al. 2010). Among southern European countries, Italy has the highest percentage of unintended fire ignitions (Catry et al. 2010), accounting for nearly $80 \%$ of the causes (Tab. 2). It is commonly thought that most ignitions are criminal (Lon 2012). However, this belief leads to underestimate the issues of poorly regulated use of fire for agricultural and pastoral purposes (Lovreglio et al. 2010, Razzoli 2011). An example is provided by the 2007 fire season: $43.2 \%$ of unintentional ignitions were attributed to negligence in stubble burning, while pastoral fires were behind $31.1 \%$ of intentional ignitions or probably more, since $56.6 \%$ of them had an unknown cause (Schmuck et al. 2008) The uncertainty on causes of wildfire fuels public alarm (Lovreglio et al. 2010), so that the use of fire is now a cultural taboo among professionals (Delogu \& Cabiddu 2009), who also share a lack of knowledge on the ecological effects of fire, and of PB in particular (Leone et al. 1999).

\section{Legislation}

In Italy, forests are subjected to land use restrictions, e.g., for hydrogeological protection $(87.1 \%$ of forest land) or landscape con- servation (100\%). Management actions must be authorized and comply with regulations and forest management plans. The longest standing of such regulations, i.e., RDL 3267/ 1923 on soil conservation, categorically banned the use of fire from forests (Calabri 1988).

PB was rarely mentioned in national regulations concerning either wildfire or silviculture (Calabri 1988, Leone et al. 1999). The first national law for wildfire protection (e.g., L. 47/1975) left the matter of PB unregulated. Similarly, regional laws that authorized PB were initially issued in only a few regions of Italy (Buresti \& Sulli 1983). While France and Portugal introduced PB in their national laws in year 2001 and 2004, respectively (Lázaro 2010), in Italy the second national law on wildfire (L. 353/2000) failed to address the matter (Bovio \& Ascoli 2012). Calabri (1981) and Leone et al. (1999) argued that the absence of clear guidelines in PB regulations, especially concerning the attribution of responsibilities in the use of fire, has de facto prevented its implementation even when the interest was there. Field experimentation, which could have provided a better understanding of fire behavior and effects in Italian ecosystems (e.g.,
Fig. 2 - Field and pasture burning in Sicily. In southern

Italy fire is commonly used to eliminate the vegetation along roads, around houses and in open fields. Fire is applied surrepti-

tiously and rarely people managing the

burn can be observed, resulting in uncontrolled fires which spread out of the area intended to be burnt.

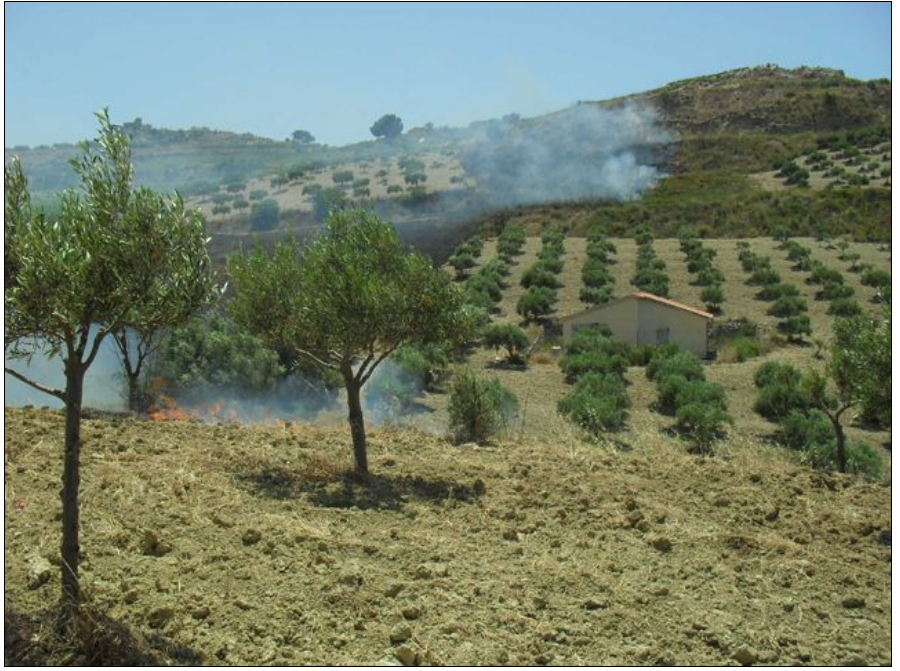

Giovannini \& Lucchesi 1997, Bovio et al. 2001, Rutigliano et al. 2007), have been limited for similar reasons (Mazzoleni \& Esposito 1993).

\section{Advances in prescribed burning in Italy}

Despite the aforementioned issues, most authors have insisted on the need to update the legislation and set up long-term multidisciplinary studies to test PB for different objectives in representative ecosystems of Italy (Susmel 1973, Calabri 1981, Buresti \& Sulli 1983, Stefani 1985, Massaiu 1999, Leone et al. 1999, Senatore 2000). However, in the recent years the regulations changed (Bovio \& Ascoli 2012). Different regions updated their legislation on wildfire, forest management and fire control planning (Fig. 3), introducing the possibility to authorize experiments and applications of PB (Delogu 2009, Leone \& Lovreglio 2009, Valese \& Held 2009, Micillo 2012). Since 2009, PB can be authorized even within Regional Parks (Ascoli et al. 2012), National Parks and State Reserves, and today 6 out of 24 National Parks include PB in their Fire Management Plans (Fig. 3).

A review of 236 normative documents dealing with fire and forests (Bovio \& Ascoli 2012) evidenced that PB is currently addressed in 14 Italian Regions, albeit with a remarkable heterogeneity in terminology, objectives and administration. The use of fire for wildfire hazard reduction is acknowledged by all Regions $(100 \%$ of the documents), and is prescribed for the reduction of litter in coniferous forests, especially in Mediterranean areas, and for fuel management in shrubby and herbaceous firebreaks (Bovio \& Ascoli 2012). Other objectives, such as range management, habitat conservation are less represented (Fig. 4a); the use of fire for silvicultural purposes is mentioned only once. The PB authorization process is regulated in $60 \%$ of the cases, but its planning (e.g., prescriptions) and the attribution of responsibilities are neglected in most of the texts (Fig. 4b).

The updated legislation, despite some limitations, has set the scene for PB experiments in many Regions (Fig. 3). Research on PB and knowledge transfer from science to practitioners have been encouraged by the active partnership of Firefighting Departments, administrations and Italian universities in international research projects on integrated fire management, such as FIRE PARADOX (Delogu 2009, Ascoli et al. 2012), ALPFFIRS (Valese et al. 2011) and PROTERINA-C (Salis et al. 2012). Italian PB experiences aimed at simultaneously achieve different management goals, such as fire hazard reduction and silvicultural prevention (Delogu 2009, Leone \& Lovreglio 2009, Valese \& Held 2009, Ascoli et al. 2010), or habitat 
Fig. 3 - The regulatory framework in Italy. Italian Administrative Regions in which prescribed burning has been experimented (light grey), and regional legal framework regulating prescribed burning (updated at 2012): Regional Law in Forest and Fire Management (black circles); Regional Fire Management Plans (crossed grey circle); Fire management Plan of National Parks (white quadrate); Fire and Forest Prescriptions (grey triangle).

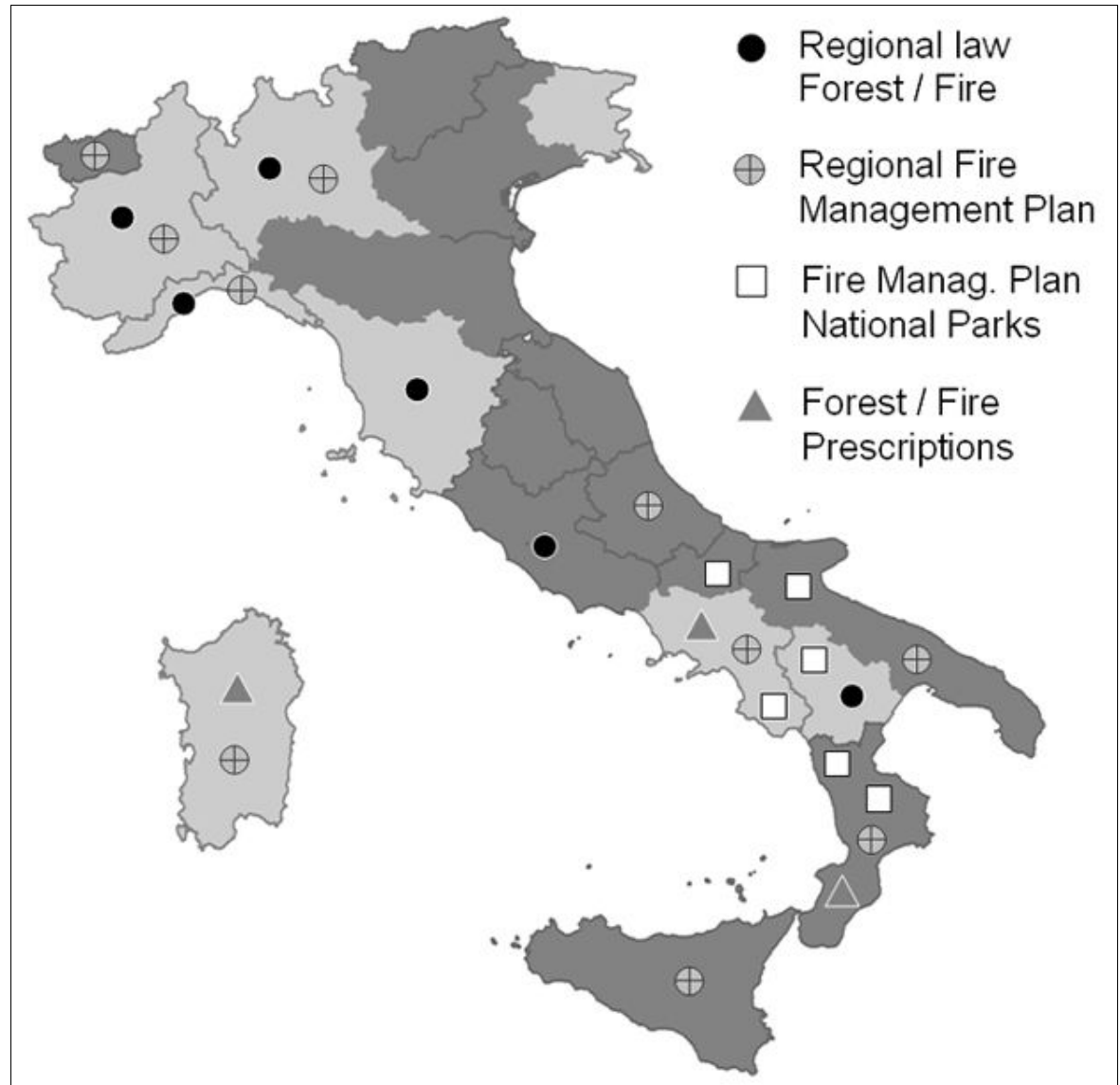

out damaging adult trees (Ascoli et al. 2012). The results were encouraging, both in terms of stand-scale hazard mitigation (Delogu 2009, Leone \& Lovreglio 2009, Valese \& Held 2009, Ascoli et al. 2010), and of fire effects on soil and vegetation (Catalanotti et al. 2010, Rutigliano et al. 2010).

A PB experiment was carried out in a fireprone Pinus halepensis forest in Cilento e Vallo di Diano National Park. One year after

burning, litter fuel load was $47 \%$ lower than the control (Ascoli et al. 2010), and 93\% lower in the herbaceous layer dominated by Ampelodesmos mauritanicus (Poir.) Dur. \& Schinz - one of the most flammable Mediterranean species (Grigulis et al. 2005). To evaluate the effectiveness of $\mathrm{PB}$ treatment in reducing fire hazard, Ascoli et al. (2010) simulated potential wildfire behavior at the stand level in treated and untreated areas (Delogu 2009, Leone $\&$ Valese \& Held 2009, Ascoli \& Bovio 2010b, Micillo 2012).

Studies on fire hazard reduction and forest management

The most common goal of PB experiences in Italy is wildfire prevention (Ascoli et al. 2012). Operations were performed in evenaged plantations of Mediterranean pines (Tab. 3), e.g., Pinus canariensis, P. halepensis, $P$. pinaster, $P$. pinea (Delogu 2009, Leone \& Lovreglio 2009, Valese \& Held 2009, Ascoli et al. 2010), but also in broadleaf forests, e.g., Eucalyptus sp., Quercus cerris (Catalanotti et al. 2012), and in continental (Ascoli et al. 2007) and Mediterranean (Salis et al. 2012) grasslands and shrub communities.

PB in conifer plantations was carried out in winter, with low intensity fires $(<150 \mathrm{~kW}$ $\left.\mathrm{m}^{-1}\right)$. The aim was to reduce fuel load and break fuel continuity in the litter layer, with- a) Management goals

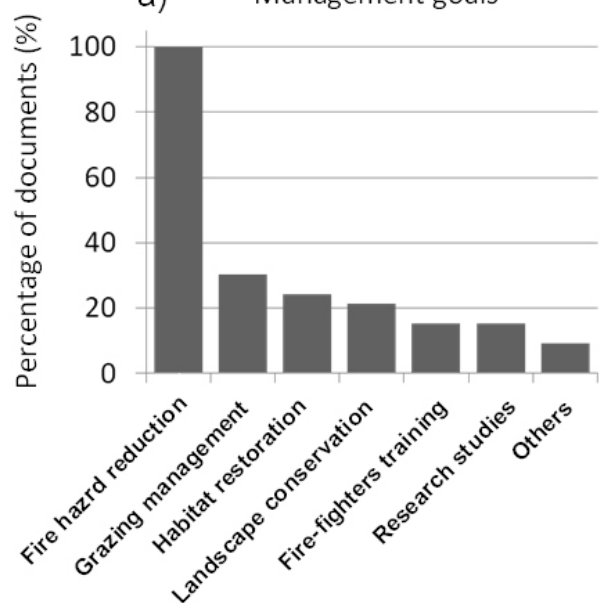

b) Contents

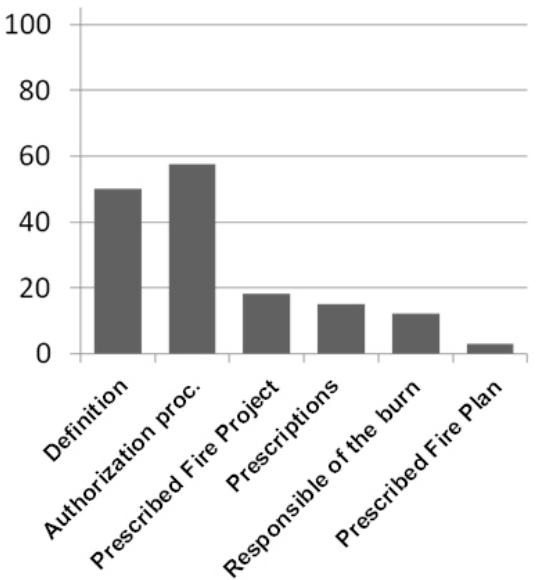

Fig. 4 - Percentage of legislative documents regulating prescribed burning in Italy (n. 34 out of 236 analyzed) by management goal (a) and contents in the text (b). Modified from Bovio \& Ascoli (2012). Data are updated to 2012. 
Tab. 3 - Prescribed burning experiences in Italy by land management goal and vegetation type.

\begin{tabular}{ll}
\hline $\begin{array}{l}\text { Management } \\
\text { goal }\end{array}$ & Vegetation type \\
\hline Fire hazard & - Conifers: Pinus canariensis; P. halepensis; P. pinaster; P. pinea. \\
reduction & - Broadleaves: Castanea sativa; Eucalyptus sp.; Quercus cerris. \\
& - Mediterranean shrubs (species: Cistus sp.; Spartium junceum). \\
& - Grasslands (dominant species: Ampelodesmos mauritanicus, Brachypodi- \\
& um sp.; Molinia sp.). \\
Forest & - Quercus cerris high forest. \\
management & - Picea abies clearcut slash. \\
Habitat & - European dry heaths with Calluna vulgaris (code HD: 4030, sub. 31.229) \\
restoration & encroached by Populus tremula and Betula pendula. \\
& - Semi-natural dry grasslands and scrubland on calcareous substrates (Fes- \\
& tuco-Brometalia - *important orchid sites) encroached by Spartium \\
& junceum. \\
& - Eastern sub-mediterranean dry grasslands (Scorzoneretalia villosae) \\
& (cod. HD: 62A0). \\
& - Lowland hay meadows (Alopecurus pratensis, Sanguisorba officinalis - \\
& cod. HD: 6510). \\
Grazing & - Grazed Quercus suber. \\
management & - Grasslands (dominant species: Molinia arundinacea; Brachypodium \\
& spp.). \\
Fire fighters & All types \\
training &
\end{tabular}

using PiroPinus, a decision support system for $\mathrm{PB}$ in Mediterranean pine forests (Fernandes et al. 2012b). Moderate, high and extreme fire weather conditions were simulated by using the $70^{\text {th }}, 90^{\text {th }}, 97.5^{\text {th }}$ percentiles of the fine dead fuel moisture distribution as estimated by PiroPinus (i.e., $11 \%, 9 \%$ and $8 \%$, respectively). Under the $97.5^{\text {th }}$ scenario, simulated headfire rate of spread, flame length and intensity in treated areas were respectively $25 \%, 69 \%$ and $88 \%$ lower than the control. The effect was attributed both to the reduction in surface fuel load, and to the breakup of vertical continuity among fuel strata (Ascoli et al. 2010). An analysis of fire effects on soil did not evidence changes in the microbial community and organic carbon content, except for short-term effects in the fermentation layer (Catalanotti et al. 2010, Rutigliano et al. 2010). Similar results were observed after PB in a Pinus pinaster stand in the Cilento Park (Catalanotti et al. 2010).

PB for managing firebreaks in herbaceous and shrub fuel beds was experimented in highly fire-prone areas, in order to evaluate its effectiveness in mitigating fire behavior at the stand (Ascoli et al. 2007) and landscape scale (Salis et al. 2012). Ascoli \& Bovio (2010b) tested the effectiveness of prescribed burning in reducing fire hazard in heathland-grass fuels, one of the most flammable fuel types in northern Italy. They analyzed fire behavior in field fire experiments under moderate weather conditions during the winter high fire danger season. A comparison was made between areas treated with PB within 3 years, and control areas where time since fire was up to 14 years. Fireline intensity was significantly reduced in prescribed burnt $v$ s. untreated areas of $74 \%$ and $80 \%$ for backfire and headfire, respectively. They showed that PB in heathland fuels is effective in reducing fire hazard at the stand level up to 3 years after treatment (Ascoli et al. 2007, Ascoli \& Bovio 2010b). In Sardinia, PB was applied in 2011 to create a network of strategic fuel breaks to protect the city of Nuoro (Salis et al. 2012). Fuel breaks in grass fuels, for a length of $12.5 \mathrm{~km}$, were realized before the beginning of the summer high fire danger season. The study showed an average $90 \%$ fuel load reduction. The analysis of the effectiveness of fuel breaks in mitigating fire risk at the landscape scale was carried out using the FARSITE fire growth model (Finney 2004). It showed that fuel breaks performed well in mitigating simulated fire behavior under low to moderate fire weather conditions, but poorly under extreme weather (Salis et al. 2012). This study stressed the effectiveness of $\mathrm{PB}$ in maintaining strategic fuel breaks, which may ease the action of fire fighting operators and provide them with anchor points for tactical fire use.

Studies in grazing management and habitat conservation

While fire prevention is the most common goal of PB in Italy, it has often been integrated by other objectives of local interest, such as range management and habitat conservation (Ascoli et al. 2012). Most of the Italian experiences are in fact the result of collaboration between stakeholders with different interests and roles: (i) firefighting au- thorities (i.e., National Forest Service, Regional Forest Service, Civil Protection), whose interest is to prevent wildfires and train staff; (ii) private forest and range owners, who wish to improve their revenues and ensure the safety of their assets; (iii) local governments, responsible for land management and planning; (iv) Park authorities, that are mostly concerned with the conservation of specific habitats and landscapes; (v) researchers. In some Regions, action was taken to resolve conflicts between the use of pastoral fire and habitat conservation goals, such as in EU Natura 2000 sites (Ascoli et al. 2009, Delogu \& Cabiddu 2009, Valese et al. 2011, Catalanotti et al. 2012). In Piedmont, an experimental program for the conservation of Calluna vulgaris Hull. (cod. 4030, Habitat Directive 92/43/CEE) has been carried out since 2005 by combining $\mathrm{PB}$ and grazing treatments (Ascoli et al. 2009). Heathlands are a cultural landscape whose conservation, once helped by periodic pastoral fire, is now threatened by its irrational application (Borghesio 2009). Upland heathlands originated in the early Middle Ages from deforestation by fire, and have been preserved thanks to continued mowing, grazing and periodic use of fire on small areas (Ascoli et al. 2009). Today, livestock density reached a minimum, and fire is being used during the period of maximum danger (i.e., in late winter), with a consequent increase in area burned (Borghesio 2009). This fire regime is in part a consequence of fire bans and the loss of traditional knowledge (Ascoli \& Bovio 2010a). Shepherds ignite fires surreptitiously, when they are sure that the fire will self-sustain and spread, so as to be able to leave the scene. These uncontrolled fires burn under severe fire weather and spread over areas far greater than those necessary for pasture management. The combination of frequent fire and infrequent grazing causes the encroachment of fire-resilient tree species (e.g., aspen Populus tremu$l a \mathrm{~L}$.) at the expense of the heather (Ascoli \& Bovio 2010a).

$\mathrm{PB}$ and grazing treatments have been replicated on small blocks since 2005 in collaboration with local shepherds, with the aim of controlling invasive grass (Lonati et al. 2009) and tree species (Ascoli et al. 2013b), restore the heathland habitat, and establish prescriptions to regulate pastoral fire (Ascoli et al. 2009). After 7 years of monitoring, results were encouraging. Medium intensity fires $\left(500-1500 \mathrm{~kW} \mathrm{~m}^{-1}\right)$ caused high mortality of aspen stems. Yearly grazing allowed to control fire induced resprouts, and resulted in a tree basal area $72 \%, 80 \%$ and $86 \%$ lower than that in the fire-only, goat browsing-only and control treatments, respectively, allowing the heather to recover (Ascoli et al. 2013b).

A similar program has been implemented 
since 2008 in the Cilento Park (Ascoli et al. 2012) for the restoration of pastures encroached by Spartium junceum L., and the conservation of semi-natural dry grasslands (cod. 6210 - Festuco-Brometalia *important orchid site, HD 92/43/CEE). Experimental burn sites have been chosen in agreement with local shepherds, who use fire regularly in the area. Two hectares were treated in 2009 and 8 ha in 2011 (Fig. 5). Assessment of the effect of PB on soil, flora (Catalanotti et al. 2012) and fauna (Romano et al. 2010) followed. Catalanotti et al. (2012) used thermocouple measurements (K-Type) to analyze the relationships between flame temperature residence times and fire effects in the soil. Because of high temperature on litter surface $\left(850^{\circ} \mathrm{C}\right)$, with a mean residence time above $100^{\circ} \mathrm{C}$ of 428 seconds, an alteration in microbial biomass and activity was found in the fermentation layer and, temporarily, also in the soil beneath. The author conclude her analysis stressing the importance of adequate control of fuel moisture levels when applying intense fire treatments to minimize hea transfer to soil and the need for fire use prescriptions targeted to this habitat (Catalanotti et al. 2012)

Valese et al. (2011) analyzed fire behavior during PB in pastures subjected to recurren pastoral fires in the southeastern Alps. Burn conditions were more conservative than in Catalanotti et al. (2012): soil temperatures were between $0-5^{\circ} \mathrm{C}$ and duff moisture content was $187 \%$ (dry weight basis). Fire temperatures were measured using thermocouples (K-Type), positioned at the soil surface and within the organic soil. Maximum flame temperature at the soil surface was $620^{\circ} \mathrm{C}$ and residence time above $100^{\circ} \mathrm{C}$ was 45 seconds. Maximum temperature in the soil was $19.5^{\circ} \mathrm{C}$, and mean residence time between 5 and $20^{\circ} \mathrm{C}$ was $171 \pm 60$ seconds. These results suggest that heat transfer to the soil can be strongly mitigated by suitable duff moisture prescriptions (Valese et al. 2011).

A prominent example of a participatory program to resolve pastoral fire use conflicts has been implemented in Sardinia (Delogu \& Cabiddu 2009), as documented on film by Ribet (2008). In Sardinia, fire is still an important cultural practice, and is considered an effective tool for the disposal of agroforestry residues, stubble, and for rangeland improvement. The Regional Forestry Service is gradually implementing an integrated fire management approach (Delogu 2012) to support shepherds, include pastoral fire within a broader fire management strategy, and, at the same time, train the operators in the expert use of fire (Delogu \& Cabiddu 2009, Salis et al. 2012).

\section{Experiences in firefighter training}

All PB experiences in Italy have provided

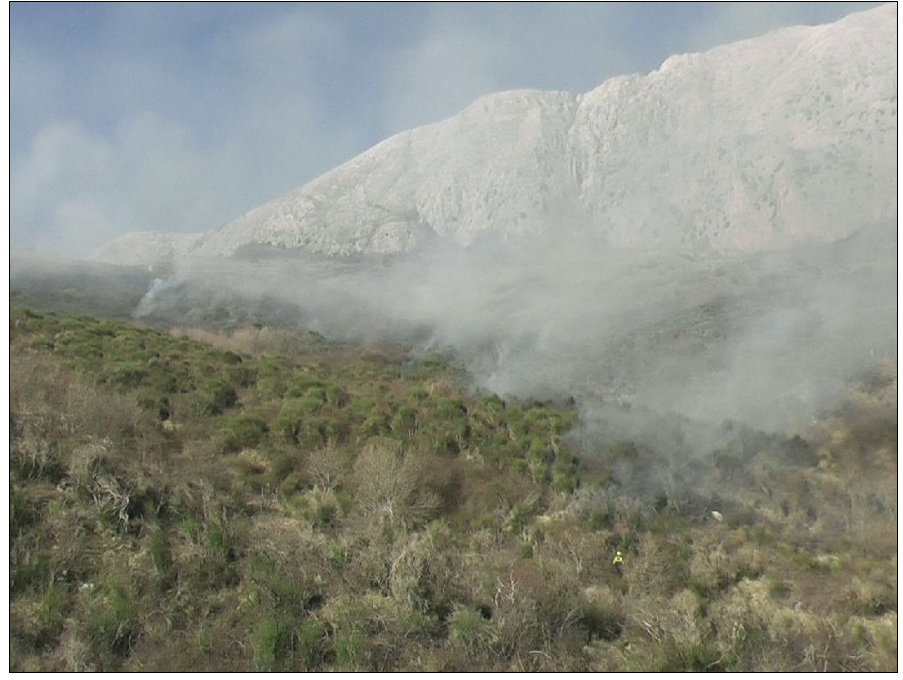

Fig. 5 - Prescribed burning in encroaching Spartium junceum shrubland in the Cilento and Vallo di Diano Park. The prescribed burning was carried out in February 2011 at Sella del Corticato. The burn covered an are of 8 ha with the objective to prevent pastoral fire use, open encroached areas for grazing and re-establish grassland habitats.

opportunities for training firefighting personnel. Courses were held between 2007 and 2012 in Basilicata (Leone \& Lovreglio 2009), Tuscany (Valese \& Held 2009), Piedmont (Ascoli \& Bovio 2010b), Campania (Ascoli et al. 2012) and Liguria (Micillo 2012). In Sardinia, an institutional team was licensed in 2008 for the use of fire (Mastros de Fogu), for both prescribed burning and fire suppression (Delogu \& Cabiddu 2009). Courses were held by both Italian and foreign professionals, such as Portuguese GIFF (http:// www.giff.pt/website/) for the training in Campania (Ascoli et al. 2012) or the French Office National des Forêts in Liguria (Micillo 2012 - Fig. 6). Recently, selected operators from firefighting services of Tuscany and Lombardy have attended training courses on $\mathrm{PB}$, in collaboration with the Catalan GRAF, and the latter practiced the technique during a study tour in Cataluña.

Despite initial skepticism on the technique, as we previously summarized (Leone et al. 1999), awareness and interest of professional operators on the subject is increasing. In this process, a key role was played by training visits of Italian personnel to France, Portugal

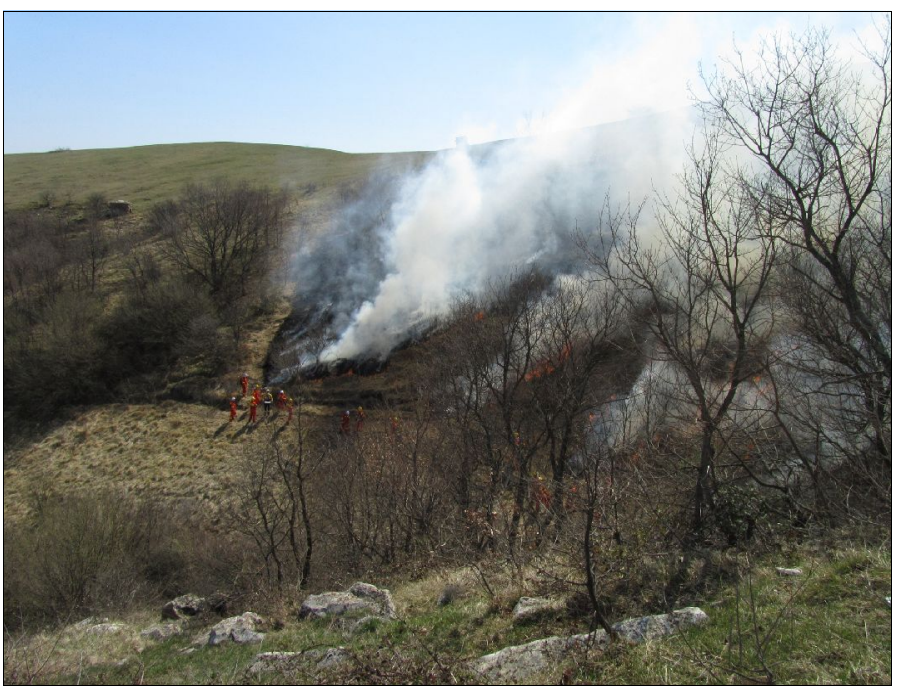

and Spain (Ascoli et al. 2012).

Classroom and field training sessions for PB planning, application and monitoring provided operators with new proficiencies and analytical skills: (i) a greater understanding of the principles of fire ecology in forest ecosystems and of fuel management for fire prevention; (ii) the ability to analyze and anticipate the behavior of the flame front as a function of vegetation, meteorological and topographical variables; (iii) the ability to use models (e.g., fire behavior fuel models) and decision support tools (e.g., fire danger ratings, fire behavior simulators); (iv) practical procedures for flame front control, workers' safety and post-fire restoration. These results confirm the high potential of $\mathrm{PB}$ in Italy for the training of firefighting personnel (Calabri 1981) and professional positions such as the Director of fire control operations and the Fire Analyst (Delogu \& Cabiddu 2009, Valese \& Held 2009), which are widely recognized and developed in European (Molina et al. 2010) and extra-European countries with highly specialized fire management systems (Kobziar et al. 2009).
Fig. 6 - Prescribed burning training in Liguria. The training course started in October 2011 ended with a field training in March 2012 within a collaboration between the Corpo Forestale dello Stato (Imperia Province), the Liguria Region and the Office National de Forêt of Corse. (Photo: G. Castiglione, CFS Imperia). 


\section{Challenges of prescribed burning in Italy}

This review shows that prescribed fire could be applied in Italy for multiple and integrated objectives: (i) managing fuel breaks in fire-prone areas with herbaceous and shrub fuel beds; (ii) periodically reducing litter fuels in mature conifer forests exposed to recurrent fires; (iii) supporting pastoral activities and range management; (iv) promoting conservation of habitats and cultural landscapes where periodical fire is an importan ecological factor; (v) firefighters training. The integrated and multidisciplinary approach adopted in most of the described experiences has allowed overcoming some issues that had been identified in the past (Calabri 1981, Stefani 1985, Leone et al. 1999). The following outcomes have resulted: (i) participatory processes in sharing PB objectives, methods and results; (ii) knowledge transfer between stakeholders; (iii) better definition of authorization protocols, technical procedures, and attributed responsibilities; (iv) recovery of traditional knowledge (Ascoli et al. 2012).

Similar results have been obtained from the established practice of PB in Europe (Silva et al. 2010), where problems and solutions were similar to those illustrated for Italy (Fernandes \& Botelho 2004, Bernard-Laurent \& Weber 2007, Davies et al. 2008, Lambert 2010, Lázaro 2010, Vélez 2010) However, as noticed by several authors (Susmel 1973, Calabri 1981, Stefani 1985, Leone et al. 1999), PB experiences from foreign countries must be weighted on the existing differences in geographic, environmental and socio-economic conditions. Applying PB in Italy requires a thorough knowledge transfer and a body of research based on repeatable experiments, carried out at an adequate spatial and temporal scale, and adopting an adaptive approach (Ascoli et al. 2009).

Open research questions still remain about where, when and how PB should be planned and used. In particular, they concern: (i) PB effectiveness for fire hazard reduction; (ii) prescribed fire regimes which maximize ecosystems services while reducing ecological concerns; (iii) technical prescriptions for burn objective and environment of application; (iv) smoke diffusion models in the RU and in areas with a complex topography; (v) the overall balance of greenhouse gas emissions, taking into account the mitigation of wildfires; (vi) the costs of $\mathrm{PB}$ in comparison to other established fuel management techniques; (vii) the need for communication and citizen awareness on the issues of fire prevention and ecology (Ascoli et al. 2012).

As regard fire hazard reduction, the PB effectiveness in abating the overall burnt area (i.e., leverage) is proportional to the wildfire area extent of a specific territory (Price 2012). When wildfire incidence on the over- all vegetation area is low, most of the treated areas are not encountered by a fire and so cannot be effective. Consequently, the low fire incidence in Italy (e.g., 1.29\% - Tab. 2) seems to not justify a PB strategy at the national level. However, fire management is set by Regional administrations (Bovio \& Ascoli 2012) which identify local priority areas where wildfire incidence is high and where $\mathrm{PB}$, implemented in a strategic spatial design (Price 2012), could be effective. Moreover, the landscape fragmentation and relatively less severe fire weather which characterize the Italian territory may increase PB effectiveness, as reported for other southern European countries (Vilén \& Fernandes 2011). Deepening these issues could improve PB planning for fire hazard reduction in highly fire-prone areas of Italy.

Research on the effects of PB regimes in specific habitats and forest ecosystems could be viewed as an opportunity for developing new research ideas in forest ecology. The Italian landscape has changed dramatically in the recent decades. Abandonment of agricultural and forest activities in mountain areas has been affecting biodiversity (Sitzia et al. 2010) and fire risk at the landscape scale (Höchtl et al. 2005). Several authors stressed the importance of increasing landscape heterogeneity also by means of prescribed fire (e.g., Moreira et al. 2011). Given the important role that fire has played in fostering biodiversity in Italian ecosystems (Sereni 1981, Delogu \& Cabiddu 2009, Conedera \& Krebs 2010, Favilli et al. 2010), there is much research potential on the effectiveness of PB for biodiversity conservation. Ascoli et al. (2012) identified several EU Natura 2000 habitats (code Habitat Directive: 2240, 2270, 4030, 6220, 62A0, 6510, 9540), in addition to marshlands dominated by Carex spp. and Phragmites australis (Cav.) Trin., in which appropriate burning prescriptions integrated within management plans could help establishing disturbance regimes compatible with the conservation of biological values. Research is increasingly demonstrating the importance of fire for natural regeneration in Italian forests, not only dominated by early-serial conifers, e.g., Larix decidua, Pinus laricio, $P$. halepensis, $P$. pinaster, $P$. pinea, $P$. sylvestris (Saracino et al. 1997, Moya et al. 2008), but also by shade tolerant species, which are usually believed to display less specific fire-adaptive traits. For example, single fire events preceding mast years could be one of the most effective regeneration pathways in old-growth beech (Van Gils et al. 2010, Ascoli et al. 2013a, Maringer et al. 2012). Further analysis could lead to reconsider the use of fire in forests, especially where landscape and habitat values are the ecosystem services at stake.

Preliminarily to introducing PB in Italy, however, appropriate regulations must be issued at the regional level, which clarify: (i) administrative responsibilities; (ii) authorization procedures of PB projects, homogeneous at the national level, quick and flexible in order to exploit the narrow window suitable for operations; (iii) safety measures; (iv) specialists required. Bovio \& Ascoli (2012) emphasized the need to regulate PB at the national level by updating the legislation on forests, parks and wildfire, and possibly framing it in a European directive on the use of fire (Montiel-Molina 2012). Finally, as is customary in other countries, it is necessary to design a professionals certification system for the planning, use and analysis of $\mathrm{PB}$, that incorporate aspects of ecology and forest management, fire behavior prediction, and fire control operations (Delogu 2009, Valese \& Held 2009, Bovio \& Ascoli 2012).

There are many issues to address in order to integrate PB in land management plans in Italy. This work provides a synthetic framework on this subject of international interest. We anticipate it to have positive effects on future research and application of prescribed burning in Italy, and contribute to the current debate on fire prevention vs. fire control policies and investments (Bovio 2006, Delogu 2012). The increasing costs of fire control and the paucity of public finances in Italy should bring under attention the opportunity for prescribed burning as one of the available strategies in integrated fire management (Moreira et al. 2011, Silva et al. 2010), in order to face fire issues in a changing society, landscape and climate.

\section{Acknowledgments}

The work was financed by the project PRIN 2009 "in FLAMING: Developing innovative models and techniques for integrated fuel management for fire prevention in Mediterranean and temperate forests" (coordinator: P. Corona) funded by the Italian Ministry for Education, University and Research. We are grateful to Giorgio Vacchiano for language revision and comments.

\section{References}

Ali AA, Roiron P, Guendon JL, Poirier P, Terral JF (2005). Holocene vegetation responses to fire events in the inner French Alps (Queyras Massif): data from charcoal and geomorphological analysis of travertine sequences. The Holocene 15 (1): 149-155. - doi: 10.1191/09596836 05hl794rr

Ascoli D, Beghin R, Ceccato R, Gorlier A, Lombardi G, Lonati M, Marzano R, Bovio G, Cavallero A (2009). Developing an adaptive management approach to prescribed burning: a long-term heathland conservation experiment in north-west Italy. International Journal of Wildland Fire 18 (6): 727-735. - doi: 10.1071/ WF07114 
Ascoli D, Bovio G (2010a). Tree encroachment dynamics in heathlands of north-west Italy: the fire regime hypothesis. iForest 3 (1): 137-143. doi: 10.3832/ifor0548-003

Ascoli D, Bovio G (2010b). Appraising fuel and fire behaviour for prescribed burning application in heathlands of Northwest Italy. In: Proceedings of the "VI International Conference on Fores Fire Research" (Viegas DX ed). Coimbra (Portugal) 15-18 Nov 2010, pp. 11

Ascoli D, Bovio G, Ceccato R, Marzano R (2007). Comportamento del fuoco e gestione della biomassa nei viali tagliafuoco: valutazione sperimentale del carico di combustibile compatibile con l'attacco diretto. L'Italia Forestale e Montana 62 (5/6): 369-383.

Ascoli D, Bovio G, Esposito A, Seneca U, Rutigliano FA, Catalanotti AE, Strumia S, Salgueiro A, Palheiro P, Rebelo A, Mazzoleni S, Fernandes $P$ (2010). Using PiroPinus to assess fuel reduction effectiveness of prescribed burning in a Pinus halepensis plantation in Southern Italy. In: Proceedings of the "VI International Conference on Forest Fire Research" (Viegas DX ed). Coimbra (Portugal) 15-18 Nov 2010, pp. 11

Ascoli D, Catalanotti A, Valese E, Cabiddu S, De$\operatorname{logu}$ G, Driussi M, Esposito A, Leone V, Lovreglio R, Marchi E, Mazzoleni S, Rutigliano F, Strumia S, Bovio G (2012). Prescribed burning experiences in Italy: an integrated approach to prevent forest fires. Forest@9 (1): 20-38. [in Italian with English summary] - doi: 10.3832/ efor0686-009

Ascoli D, Castagneri D, Valsecchi C, Conedera M, Bovio G (2013a). Post-fire restoration of beech stands in the Southern Alps by natural regeneration. Ecological Engineering. - doi: 10.1016/j.ecoleng.2013.01.032

Ascoli D, Lonati M, Marzano R, Bovio G, Cavallero A, Lombardi G (2013b). Prescribed burning and browsing to control tree encroachment in southern European heathlands. Forest Ecology and Management 289: 69-77. - doi: 10.1016/j.foreco.2012.09.041

Bernard-Laurent A, Weber F (2007). Prescribed-burning in Mercantour: practical knowledge, social relations and decision-processes. Natures Sciences Sociétés 15 (3): 233-244. [in French with English summary] - doi: 10.1051/ nss:2007056

Borghesio L (2009). Effects of fire on the vegetation of a lowland heathland in North-western Italy. Plant Ecology 201 (2): 723-731. - doi: 10.1007/s1 1258-008-9459-1

Bovio G, Callegari G, Camia A, Francesetti A, Iovino F, Porto P, Veltri A (2001). Prove sperimentali per valutare l'impatto degli incendi boschivi sull'idrologia superficiale e sull'erosione dei suoli. L'Italia Forestale e Montana 56 (4): 233-256.

Bovio G (2006). Planning against forest fires: prevention more than extinction. Forest@ 3 (2): 156-158. [in Italian with English Summary] doi: 10.3832/efor0380-003

Bovio G, Ascoli D (2012). Fuoco prescritto: stato dell'arte della normativa in Italia. L'Italia Fore- stale e Montana 67 (4): 347-358.

Buresti E, Sulli M (1983). Il fuoco strumento colturale? Annali dell'Istituto Sperimentale per la Selvicoltura, Arezzo (Italy) 16: 355-385.

Calabri G (1981). Il fuoco prescritto, una discussa tecnica per la gestione dei boschi. Monti e boschi 32 (1): 35-42.

Calabri G (1988). L'introduction du brûlage contrôlé en Italie. In: Proceedings of the "Atelier sur le brûlage contrôlé". Avignon (France) 14-18 Mars 1988. INRA-FAO-IUFRO, Avignon, France.

Carcaillet C, Ali AA, Blarquez O, Genries A, Mourier B, Bremond L (2009). Spatial variability of fire history in subalpine forests: from natural to cultural regimes. Ecoscience 16 (1): 112. - doi: 10.2980/16-1-3189

Catalanotti AE, Strumia S, Esposito A, Ascoli D, Marzaioli R, Seneca U, D’Ascoli R, Mazzoleni S, Rutigliano FA (2010). Effects of prescribed burning on soil microbial community and vegetation in pine plantations of southern Italy. In: Proceedings of the "VI International Conference on Forest Fire Research" (Viegas DX ed). Coimbra (Portugal) 15-18 Nov. 2010, pp. 11.

Catalanotti AE, Esposito A, Ascoli D, Marzaioli R, Strumia S, D'Ascoli R, Mazzoleni S, Rutigliano FA (2012). Applications of prescribed fire in different ecosystem types: effects on soil microbial community. In: Proceedings of the "XXII Congresso della Società Italiana di Ecologia". Alessandria (Italy) 10-13 Sep 2012.

Catry FX, Rego FC, Silva JS, Moreira F, Camia A, Ricotta C, Conedera M (2010). Fire Starts and Human Activities. In: "FIRE PARADOX White Book: towards integrated fire management - outcomes of the European project Fire Paradox (Silva JS, Rego FC, Fernandes P, Rigolot E eds). Research Report 23, European Forest Institute, Joensuu, Finland, pp. 9-22.

Conedera M, Krebs P (2010). La pratica del fuoco pastorale nella Svizzera sudalpina dal tardo $\mathrm{Me}$ dioevo ai nostri giorni. In: Proceedings of the meeting "Al fuoco! Usi, rischi e immaginari collettivi dal Medioevo al XX secolo" (Lorenzetti L, Giannò V eds). Mendrisio (Sondro - Italy) 15-17 Nov 2007. LabiSAlp ed., Giampiero Casagrande Ed., Milan, Italy, pp. 191-215.

Corona P, Barbati A, Tomao A, Bertani R, Valentini R, Marchetti M, Fattorini L, Perugini L (2012). Land use inventory as framework for environmental accounting: an application in Italy. iForest 4: 204-209. - doi: 10.3832/ifor0625-005 Davies M, Gray A, Hamilton A, Legg C (2008). The future of fire management in the British uplands. International Journal of Biodiversity Science, Ecosystems Services \& Management 4 (3): 127-147. - doi: 10.3843/Biodiv.4.3:1

Delogu G (2009). Esperienze di "Prescribed Burning" in Sardegna. In: Proceedings of the "III Congresso Nazionale di Selvicoltura". Taormina (CT - Italy) 16-19 Oct 2008. Accademia Italiana di Scienze Forestali, Firenze, Italy, pp. 12931296.

Delogu G, Cabiddu S (2009). Fuoco prescritto e controfuoco in Sardegna, tra tradizione ed attual- ità: quali prospettive? In: "La gestione della difesa dagli incendi boschivi" (Fondazione S. Giovanni Gualberto - Osservatorio Foreste e Ambiente ed). I Quaderni 9: 57-87.

Delogu G (2012). Living with fire? Sardegna Democratica. [in Italian] [online] URL: http://www.sardegnademocratica.it/ambiente/living-with-fire-1.28229

Falcucci A, Maiornao L, Boitani L (2007). Changes in land-use/land-cover patterns in Italy and their implications for biodiversity conservation. Landscape ecology 22: 617-631. - doi: 10.1007/s10980-006-9056-4

Favilli F, Cherubini P, Collenberg M, Egli M, Sartori G, Schoch W, Haeberli W (2010). Charcoal fragments of Alpine soils as an indicator of landscape evolution during the Holocene in Val di Sole (Trentino, Italy). The Holocene 20 (1): $67-$ 79. - doi: 10.1177/0959683609348850

Fernandes P, Botelho H (2004). Analysis of the prescribed burning practice in the pine forest of northwestern Portugal. Journal of Environmental Management 70 (1): 15-26. - doi: 10.1016/j.jenvman.2003.10.001

Fernandes PM, Loureiro C, Palheiro P, ValeGonçalves H, Fernandes MM, Cruz MG (2012a). Fuels and fire hazard in blue gum (Eucalyptus globulus) stands in Portugal. Boletín del CIDEU 10: 53-61.

Fernandes PM, Loureiro C, Botelho H (2012b). PiroPinus: a spreadsheet application to guide prescribed burning operations in maritime pine forest. Computers and Electronics in Agriculture 81: 58-61. - doi: 10.1016/j.compag.2011.11.005 Finney MA (2004). FARSITE: Fire Area Simulator - model development and evaluation. Research Paper RMRS-RP-4 Revised, Rocky Mountain Research Station, USDA Forest Service, Ogden, Utah, USA, pp. 47.

Fiorucci P, Galardi M, Negro D, Gollino A (2011). On the right track? Wildfire Magazine. [online] URL: http://wildfiremag.com/wui/italywildfire-fight-201103/

Giovannini G, Lucchesi S (1997). Modifications induced in soil physicochemical parameters by experimental fires at different intensities. Soil Science 162: 479-486. - doi: 10.1097/00010694199707000-00003

Granström A (2001). Fire management for biodiversity in the European boreal forests. Scandinavian Journal Forest Research 3: 62-69. - doi: 10.1080/028275801300090627

Grigulis K, Lavorel S, Davies ID, Dossantos A, Lloret F, Vilà M (2005). Landscape-scale positive feedbacks between fire and expansion of the large tussock grass, Ampelodesmos mauritanica in Catalan shrublands. Global Change Biology 11: 1042-1053. - doi: 10.1111/j.1365-2486. 2005.00980.x

Genries A, Morin X, Chauchard S, Carcaillet C (2009). The function of surface fires in the dynamics and structure of a formerly grazed old subalpine forest. Journal of Ecology 97: 728741. - doi: 10.1111/j.1365-2745.2009.01518.x Höchtl F, Lehringer S, Konold W (2005). "Wilderness": what it means when it becomes a rea- 
lity - a case study from the southwestern Alps. Landscape and Urban Planning 70 (1): 85-95. doi: 10.1016/j.landurbplan.2003.10.006

INFC (2005). Inventario nazionale delle foreste e dei serbatoi forestali di carbonio. Ministero delle Politiche Agricole Alimentari e Forestali, Ispettorato Generale - Corpo Forestale dello Stato, Rome, Italy. CRA - Unità di ricerca per il Monitoraggio e la Pianificazione forestale, Rome, Italy.

Kilgore BM (1976). From fire control to fire management: an ecological basis for policies. In: Transactions of the " $41^{\text {st }}$ North American Wildlife and Natural Resources Conference”, 1976, pp. 17.

Kobziar LN, Rocca ME, Dicus CA, Hoffman C, Sugihara N, Thode AE, Varner JM, Morgan P (2009). Challenges to educating the next generation of wildland fire professionals in the United States. Journal of Forestry 107 (7): 339-345.

Lambert B (2010). The french prescribed burning network and its professional team in Pyrénées Orientales: lessons drawn from 20 years of experience. In "Best practices of Fire Use. Prescribed Burning and Suppression Fire Programs in selected Case-Study Regions in Europe" (Montiel C, Krauss D eds). Research Rep. 24, European Forest Institute, Joensuu, Finland, pp. 17-31.

Lázaro A (2010). Development of prescribed burning and suppression fire in Europe. In: "Best practices of fire use. Prescribed burning and suppression fire programs in selected case-study regions in Europe" (Montiel C, Krauss D eds). Research Rep. 24, European Forest Institute, Joensuu, Finland, pp. 17-31.

Leone V, Signorile A, Gouma V, Pangas N, Chronopoulous-Sereli (1999). Obstacles in prescribed fire use in Mediterrean countries: early remarks and results of the Fire Torch project. In: Proceedings of the "DELFI International Symposium. Forest Fires: Needs and Innovations". Athens (Greece) 18-19 Nov 1999, pp. 5.

Leone V, Lovreglio R (2009). Il fuoco come strumento nella gestione preventiva e tattica. In: "La gestione della difesa dagli incendi boschivi". (Fondazione S. Giovanni Gualberto - Osservatorio Foreste e Ambiente ed). I Quaderni 9: 7190.

Lon G (2012). Allarme incendi in Italia. I boschi vanno in fumo. La Stampa, Anno 146 (210): 1213.

Lonati M, Gorlier A, Ascoli D, Marzano R, Lombardi G (2009). Response of the alien species Panicum acuminatum to disturbance in an Italian lowland heathland. Botanica Helvetica 119: 105 111. - doi: 10.1007/s00035-009-0063-3

Lovreglio R, Leone V, Giaquinto P, Notarnicola A (2010). Wildfire cause analysis: four case-studies in southern Italy. iForest 3: 8-15. - doi: 10.3832/ ifor0521-003

Maringer J, Wohlgemuth T, Neff C, Pezzatti GB, Conedera M (2012). Post-fire spread of alien plant species in a mixed broad-leaved forest of the Insubric region. Flora 207: 19-29. - doi: 10.1016/j.flora.2011.07.016
Massaiu A (1999). Il fuoco come tecnica di gestione territoriale. Applicazione di fuoco prescritto in Sardegna. B.Sc. thesis, University of Florence, Italy, pp. 144.

Mazzoleni S, Esposito A (1993). Vegetative regrowth after fire and cutting of Mediterranean macchia species. In: "Fire in Mediterranean ecosystems" (Trabaud L, Prodron R eds). Ecosystems Research Report no. 5, European Community, Brussels, Belgium, pp. 87-99.

Mazzoleni S, Bellelli M, Esposito A, Ricotta C, Di Pasquale G, Blasi C (2001). Incendi e paesaggio vegetale: il caso del Cilento, Campania. Italia Forestale e Montana 6: 417-429.

McArthur AG (1969). Fire as an ecological tool in conserving natural resources. Riverina Conf. Papers no. 2, Inst. of Riverina Studies, Wagga Wagga, New South Wales, Australia, pp. 1-10.

Micillo F (2012). A scuola di fuoco prescritto con il Corpo Forestale dello Stato. Quaderni della Protezione Civile, Note di antincendio boschivo 5: 36-42.

Molina D, Castellnou M, García-Marco D, António S (2010). Improving fire management success through fire behaviour specialists. In: "Towards Integrated Fire Management - Outcomes of the European Project Fire Paradox" (Silva JS, Rego F, Fernandes P, Rigolot E eds). Research Report 23, European Forest Institute, Joensuu, Finland, pp. 105-119.

Montiel-Molina C (2012). Comparative assessment of wildland fire legislation and policies in the European Union: Towards a Fire Framework Directive. Forest Policy and Economics. - doi: org/10.1016/j.forpol.2012.11.006

Moreira F, Viedma O, Arianoutsou M, Curt T, Koutsias N, Rigolot E, Barbati A, Corona P, Vaz P, Xanthopoulos G, Mouillot F, Bilgili E (2011). Landscape - wildfire interactions in southern Europe: Implications for landscape management. Journal of Environmental Management 92 (10): 2389-2402. - doi: 10.1016/j.jenvman.2011.06. 028

Moya D, Saracino A, Salvatore R, Lovreglio R, de Las Heras J, Leone V (2008). Anatomic basis and insulation of serotinous cones in Pinus halepensis Mill. Trees 22: 511-519. - doi: 10.1007/s00468-008-0211-1

Price OF (2012). The drivers of effectiveness of prescribed fire treatment. Forest Science 58 (6): 606-617. - doi: 10.5849/forsci.11-002

Puettmann KJ, Coates KD, Messier C (2009). A critique of silviculture. Managing for complexity. Island Press, Washington, DC, USA.

Pyne SJ (1982). A cultural history of wildland and rural fire. Princeton University Press, Princeton, MS, USA.

Pyne SJ (1997). Vestal fire: an environmental history told through fire, of Europe and Europe's encounter with the world. University of Washington Press, Seattle, WA, USA.

Razzoli E (2010). Il fuoco tra natura e cultura. Analisi dell'uso sociale del fuoco nella manipolazione del paesaggio. B.Sc. thesis, University of Florence, Italy, pp. 259. [in Italian]

Razzoli E (2011). Fuochi nascosti in esperienze remote e nell'immaginario umano, tra natura e cultura. I Quaderni del Ramo d'Oro 4: 78-99.

Ribet N (2008). Les maîtres feu. Fire Paradox. Web site. [in French] [online] URL: https:// sites.google.com/site/doc2geo/visionner/les-mai tres-feu

Romano A, Salvidio S, Esposito A, Mazzoleni S (2010). Valutazione degli effetti del fuoco prescritto sull'erpetofauna nel Parco Nazionale del Cilento e Vallo di Diano (Campania): messa a punto della metodologia di campionamento. In: Proceedings of the "VIII Congresso Nazionale Societas Herpetologica Italica" (Di Tizio L, Di Cerbo AR, Di Francesco N, Cameli A eds). Ianieri Ed., Pescara, Italy, pp. 509-514.

Rutigliano FA, De Marco A, D’Ascoli R, Castaldi S, Gentile A, Virzo de Santo A (2007). Impact of fire on fungal abundance and microbial efficiency in $\mathrm{C}$ assimilation and mineralisation in a Mediterranean maquis soil. Biology and Fertility of Soils 44 (2): 377-381. - doi: 10.1007/s00374007-0214-X

Rutigliano FA, Catalanotti AE, Marzaioli R, Ascoli D, D'Ascoli R, Strumia S, Esposito A, Mazzoleni S (2010). Soil microbial metabolism and organic carbon pools as affected by prescribed burning in pine plantations of Southern Italy. In: Proceedings of the "VI International Conference on Forest Fire Research" (Viegas DX ed). Coimbra (Portugal) 15-18 Nov 2010, pp. 9.

Salis M, Diana G, Casula F, Farris G, Farris O, Licheri F, Musina G, Orotelli S, Peluffo L, Pirisi AM, Bacciu V, Fois C, Sirca C, Spano D (2012). Potential effects of prescribed burning and tactical fires on fire risk mitigation. In: Proceedings of the "International Conference on Fire Behaviour and Risk Focus on Wildland Urban Interfaces". Alghero (SS), 4-6 Oct 2011, pp. 6.

Saracino A, Pacella R, Leone V, Borghetti M (1997). Seed dispersal and changing seed characteristics in a Pinus halepensis Mill. forest after fire. Plant Ecology 130 (1): 13-19. - doi: 10.1023/A:1009765129920

Schmuck G, San-Miguel-Ayanz J, Camia A, Kucera J, Libertà G, Boca R, Durrant T, Amatulli G (2008). Forest fires in Europe 2007. EUR 23492 EN, JRC 47446, JRC Scientific and Technical Reports, Ispra, Italy. [online] URL: http://forest. jrc.ec.europa.eu/media/cms_page_media/9/01forest-fires-in-europe-2007.pdf

Schmuck G, San-Miguel-Ayanz J, Camia A, Durrant T, Santos de Oliveira S, Boca R, Whitmore C, Giovando C, Libertà G, Corti P (2011). Forest Fires in Europe 2010. EUR 24910 EN, JRC 66167, JRC Scientific and Technical Reports, Ispra, Italy. [online] URL: http://forest.jrc.ec. europa.eu/media/cms_page_media/9/forest-firesin-europe-2010.pdf

Schulze ED, Mischì G, Asche G, Börner A (2007). Land-use history and succession of Larix decidua in the Southern Alps of Italy - an essay based on a cultural history study of Roswitha Asche. Flora 202 (8): 705-713. - doi: 10.1016/j.flora.2007.05.003

Senatore G (2000). Il fuoco prescritto: discussa tecnica di gestione di risorse silvo-pastorali. 
L'Italia Forestale e Montana 55 (1): 41-50.

Sereni E (1981). Terra nuova e buoi rossi ed altri saggi per una storia dell'agricoltura Europea. Einaudi, Torino, Italy, pp. 371.

Silva JS, Rego FC, Fernandes P, Rigolot E (2010). FIRE PARADOX White Book: towards integrated fire management. Outcomes of the European project Fire Paradox. Research Rep. 23, European Forest Institute, Joensuu, Finland, pp. 228.

Sitzia T, Semenzato P, Trentanovi G (2010). Natural reforestation is changing spatial patterns of rural mountain and hill landscapes: a global overview. Forest Ecology and Management 259. 1354-1362. - doi: 10.1016/j.foreco.2010.01.048

Stefani A (1985). Bruciare o non bruciare? Economia montana 4: 3-9.

Susmel L (1973). Development and present problems of forest fire control in the Mediterranean region. FAO, Rome, Italy, pp. 100.

Susmel L (1977). Ecology of systems and fire management in the Italian Mediterranean region. In: Proceedings of the symposium "Environmental consequences of fire and fuel management in Mediterranean ecosystems" (Mooney HA. Conrad CE eds). Palo Alto (CA - USA) 1-5 Aug 1977. Gen. Tech. Rep. WO-3, USDA Forest
Service, Washington, DC, USA, pp. 307-317. Tinner W, Conedera M, Ammann B, Lotter AF (2005). Fire ecology north and south of the Alps since the last ice age. The Holocene 15 (8): 1214-1226. - doi: 10.1191/0959683605hl892rp

Valese E, Held A (2009). La gestione dei combustibili forestali e la difesa delle proprietà private dagli incendi boschivi: il progetto pilota Pianacci (Lastra a Signa - Firenze). In: Proceedings of the "III Congresso Nazionale di Selvicoltura". Taormina (CT - Italy), 16-19 Oct 2008. Accademia Italiana di Scienze Forestali, Firenze, Italy, pp. 5.

Valese E, Driussi M, Held AC, Gottardo E, Ascoli D, Anfodillo T (2011). The pilot project Ohonj na Buonah to study the application of prescribed burning in the Eastern Alps of Italy (Friuli Venezia Giulia Region). In: Proceedings of the "V International Wildland Fire Conference" (Afri-FireNet ed). Sun City (South Africa), 9-14 May 2011, pp. 11.

Vallauri DR, Aronson J, Barbero M (2002). An analysis of forest restoration 120 years after reforestation on badlands in the southwestern Alps. Restoration Ecology 10 (1): 16-26. - doi: 10.1046/j.1526-100X.2002.10102.x

Van Gils H, Odoi T, Andrisano T (2010). From monospecific to mixed forest after fire: an early forecast for the montane belt of Majella, Italy. Forest Ecology and Management 259 (3): 433 439. - doi: 10.1016/j.foreco.2009.10.040

Vanha-Majamaa SL, Ryömä R, Kotiaho JS, Laaka-Lindberg S, Lindberg H, Puttonen PT, Toivanen T, Kuuluvainen T (2007). Rehabilitating boreal forest structure and species composition in Finland through logging, dead wood creation and fire: the EVO experiment. Forest Ecology and Management 250 (1-2): 77-88. - doi: 10.1016/j.foreco.2007.03.012

Vélez R (2010). Prescribed burning for improved grazing and social fire prevention: the spanish EPRIF programme. In: "Best practices of fire use - prescribed burning and suppression fire programs in selected case-study regions in Europe" (Montiel C, Krauss D eds). Research Report 24, European Forest Institute, Joensuu, Finland, pp. 117-122.

Vilén T, Fernandes PM (2011). Forest fires in Mediterranean countries: $\mathrm{CO}_{2}$ emissions and mitigation possibilities through prescribed burning. Environmental Management 48: 558-567. doi: 10.1007/s00267-011-9681-9 